\title{
Contemporary China and the "Harmonious" World Order in the Age of Globalization
}

\author{
Orazio Coco \\ The University of Hong Kong, Hong Kong, China \\ oraziohk@connect.hku.hk
}

\begin{abstract}
This paper examines the Chinese political vision of the world order and how the West has, so far, reacted to the presence of a new rising power in the global system. It takes inspiration from the current complex international scenario of confrontation between China and the West. The concept of socialist "harmonious" world order is not a political creative idea, but the long-term vision proposed by China since the beginning of this century. It has become topic of political interest, attracting the attention of the Western world, only in the last decade and in connection with the theoretical debate inspired by the power transition theory. The idea of a hegemonic transition and the making of a new international order, as alternative to the liberal democratic model, is gaining consistency with the economic development and the growing political influence of China, but also as consequence of the retreat of democracy worldwide.
\end{abstract}

\section{Keywords}

global governance - international world order - contemporary China - harmonious world order

\section{Introduction}

A common and misleading attitude in the Western world when studying Chinese international policy and relations is evaluating Chinese strategies and decisions according to Western interests and values and explaining China's actions and reactions as an expression of Western ideas and mentality. 
Since the end of the Cold War, the centre of gravity in international politics has dramatically shifted from Europe to Asia and from the Atlantic to the Pacific. China has increasingly taken an active role in international affairs and promoted unprecedented global initiatives (i.e. One Belt One Road), taking a responsible role in international relations and contributing to scientific and technological advancement. The fast rate of development achieved by its economy has increased the power and influence of China in the world. However, its augmented political and economic presence in international affairs has been identified as a potential challenge and often as a threat to the Western world.

In this context, global society has witnessed an escalation of political tensions involving leading (Western) international powers and their ascending Chinese rival. The increase in tone in the political dialectic has not caused irreparable damage, but it certainly has filled the ongoing disputes with unnecessary rhetoric. Diplomacy, from all sides, has so far contained the consequences, as the parties are also aware of the risks of international destabilisation in initiating any kind of global conflict, for example, in the context of the latest trade war between China and the United States.

Overall, the contemporary political debate shows that the global community has widely acknowledged the rise of a new powerful political and economic presence in the world order. China's leadership has successfully undertaken a long-term process of structural and ideological changes involving domestic and international policies, developing its own socio-economic model of growth, which, in many ways, has surprised the international liberaldemocratic system, including the United States, and is currently considered an alternative to the Western model.

Since the early 1990s, China has opened its doors to a new kind of collaboration with the West. Under the leadership of Deng Xiaoping (1904-1997), the country initiated a process of reforms involving important changes in economic domestic policies. These reforms aimed to improve the general standard of living of the population and use China's own capability and resources to lead the country beyond the borders of a developing country towards the advanced world to - to borrow the American political motto - 'make China great again'. To achieve this goal, China increasingly accepted the industrial presence of global multinationals, attracted foreign investments to its own territory, regulated capital inflow and outflow and finally joined international organisations, 
such as the World Trade Organization (WTO), to become an effective member of global society and economy.

In pursuing the policy of an 'open door' to the rest of the world, China has not forgotten the memories of the past and its experience of a semi-colonisation period, which brought the country to witness a century of humiliating consequences caused by the leading international powers until World War II. Chinese leadership has erected fences of protection, domestic and international, to avoid repeating the same situations that occurred in the dark ages (1850s-1940s).

Today's new policies have the common goals of defending without hesitation its own sovereignty from foreign interferences and pursuing international recognition as well as political and economic equality for China among the nations of the world. Overall, this process has so far successfully led the country to achieve all these fundamental objectives. From an international perspective, this is indeed a proper and commendable achievement. Why then have the economic development and the new political role of China raised so much suspicion and concern in the Western World?

From a political point of view, the emergence of China as an international power shows that the remarkable successes of the Chinese in economic development are also the achievement of growth and stability reached by the one-party political system, which is more resilient and more resisting to any political change and adversity than the most liberal democratic Western societies, which often politically shift from one majority and leadership to another. At the same time, China's achievements in fast industrial modernisation and its implementation of successful domestic social reforms have given confidence to the Chinese political leadership to finally claim for China a greater and more influential international role, which has never been accomplished before, and to propose its own societal model as an expression of the new 'socialist' alternative to the global 'liberal' leadership of the United States.

As a consequence of such a potential challenge to the Western world, American and Chinese civil societies, through their frontline scholars and politicians, have started a controversial debate based on different assumptions and ideological points of view. First to emerge was the concept of 'clash of civilisations' proposed by American professor Samuel Huntington, ${ }^{1}$ who stated the inevitability of future conflicts among diverse cultures. Huntington's concept was an initial warning to the West that ongoing cultural and religious developments in the world order would cause geopolitical changes in the future of the global society. This theory inspired controversial comments and

1 Huntington, S. (1996). The Clash of civilizations. Simon \& Schuster. 
reactions on the influence of culture and religion in explaining conflicts and changes in the geopolitical international order. In recent years, Chinese scholars have proposed the opposite version of this worrying vision, suggesting instead that civilisations have the inner drive to contribute to peaceful coexistence. ${ }^{2}$ The future of the world is linked to increased communication and connectivity among nations and cultures and to the process of exchanging values being the only true source of progress and civilisation.

The theory of the so-called Thucydides trap has recently emerged. This political interpretation of history was proposed by another American scholar, Harvard professor Graham Allison, based on the scripts of the Greek general and historian Thucydides ( $\mathrm{V}$ century BC) on how fear could escalate the powers to war. The logic of the original ancient text, conveniently adapted to the present geopolitical situation, explains how the emergence of a rising power can ignite war when the existing power intends to protect its own leading position. Through other comparisons and historical evidence, the theory assumes that the United States and China are inevitably 'destined for war'. To this theory, the Chinese political leadership firmly responded that a similar argument to the Thucydides trap does not exist in Chinese politics and that the term does not apply to China. ${ }^{3}$

These assumptions and theories have become a common challenge for politicians and public opinion and clearly do not help solve the differences in political standing points. Some American scholars, such as Richard Nisbett, ${ }^{4}$ have scientifically interpreted this ongoing misunderstanding of ideas and actions and explained the cultural and philosophical differences originating from them, starting from the profound diversity in the way of thinking (dialectical for Oriental people and logical for Occidental people). This basic difference translates to a constant differing attitude in approaching reality that causes continuous misleading interpretations of facts and behaviour. The practical and logical approach of the Western mentality often collides with the conceptual, strategic way of thinking in the Asian behaviour. The concrete evidence of this dichotomy is the astonishing development of China in the last

2 Wen J., It's not a clash but a coalition of civilisations that China wants, The Independent; London (UK) [London (UK)] 1o Nov 2009: 34 (source ProQuest); Chen, D. and Hu, J. (2019). No, There Is No US-China 'Clash of Civilizations', The Diplomat, 8 May 2019 (searched day 26 July 2019).

3 Xi Jinping, quoted in China lacks the 'Gene' to fall into the Thucydides trap, says Xi Jinping, Yicai Global 第一财经, September 20, 2017 (searched 5 June 2019).

4 Nisbett, R. (2003). The Geography of Thought: How Asians and Westerners Think Differently ... and why, New York, Free Press. 
three decades. In 2009, Henry Kissinger, in one of his enlightening speeches, ${ }^{5}$ recalled the American industrialists visiting China in the late 1970s and their depressing comments upon returning from their journey. These industrialists concluded that there was no future for fast industrial development in China. Less than a decade later, the long-term vision of Deng Xiaoping's reform plan completely changed this perspective to initiate the most intense and successful process of economic development in history.

In matters of foreign policies and global strategies, Chinese leadership emphasises that its own intentions are clearly peaceful. Several expressions have been used in time, such as the 'peaceful rise' or 'responsible power', but in many ways these definitions have not convinced the West of the good intentions of the Chinese. Instead, these publicly declared peaceful expressions have raised suspicion and mistrust because they are usually interpreted by Western observers as a renewed version of the ancient Chinese dream of 'great harmony in the world' (Tiānxià Dàtóng) under one supreme leadership. ${ }^{6}$

This last aspect deserves more attention and consideration to explain further the differences in the perspective of world governance. Whereas in the rest of the world governance is gradually evolving towards new forms of organisation as in Europe, where countries have accepted to surrender-so far partially - their own sovereignty to create a supranational entity, the principles of sovereignty and territorial integrity in China are the solid foundation of the state policy now as in a thousand years previously. In the current still Westphalian international order, China presents itself as a rigorous member of the integrated system of sovereign governments that proclaims and protects these inviolable principles with an intact and unchallenged sense of national identity. These characteristics make China a pro-status quo member of the global order, especially when it is time to respond to important international affairs. However, most influential Western powers identify China as a 'revisionist' country ${ }^{7}$ aiming to change the world order as a subverting power that undermines the unrestrainable process of democracy expansion. The

5 Kissinger, H. (2009). China Rise and China-US relations, speech at Macao Polytechnic on 11 May 2009 in Yee, H.S. (edited by). (2010). China's rise — threat or opportunity? Routledge.

6 Callahan, W. (2008). Chinese vision of the world order: post hegemonic or a new hegemony? International Study Review (2008) 10, 749-761; Friedman, E. (2010). A Challenge to the Peaceful Rise of World Power in China in Yee, H.S. (Ed.) China's rise - threat or opportunity? Routledge Security in Asia Series; Chan, S. (2007). China, the US and the power-transition theory: A critique. Routledge.

7 Chan, S. (2015). On States' Status-Quo and Revisionist Dispositions: Discerning Power, Popularity and Satisfaction from Security Council Vetoes, Issues and Studies; Taipei Vol. 51, Iss. 3, (Sep 2015): 1-28. 
controversy between the (Western) arguments and the evidence of Chinese policies in matters of sovereignty reveals an astonishing example of how China is often misinterpreted and seems aligned with defending the current order not less than that of the United States. It is probably too simplistic to attribute label or motivation without questioning the intentions of the 'challenger'. These facts and arguments reflect some reasons why China's position in the current international order is so controversial and why the Chinese leadership's vision of the common destiny involving China and the world is widely feared as a deceiving strategy of power.

In matters of international relations, Chinese political leadership seems to propose a 'balancing' role for China in the current geopolitical system, and the evident successes China has achieved in economic development and social policies provide proof of its policy effectiveness and ability to perform this strategic role. However, all Chinese decisions seem to remain determined in isolation from the rest of the world, although they are related to the contexts of global interest.

The first theory on this 'balancing' role was made by former Chinese president $\mathrm{Hu}$ Jintao in 2005, when he mentioned in several speeches the need to jointly (with other nations) construct a harmonious world. ${ }^{8}$ Consistent with China's own fundamental ideology, the concept proposed to the world is that one of a 'harmonious socialist society. ${ }^{9}$ The word 'socialist' makes a substantial distinction in presenting the Chinese societal model and comparing it with the current vision of international order mainly inspired by liberal progressive ideas of Western conception. When interpreting the goals of a harmonious society, there is not only the expression of the need for harmonising one's own territory, for example, through domestic reforms but also the plan to influence the international society with one's own culture and ideas. In examining the underlying foundations of this political concept, one should not forget that Chinese decisions in foreign affairs are subordinated to the overriding domestic policies and objectives. In international matters, internal interests lead the

8 For instance: in Jakarta (22 April 2005) during the meeting of the Association of the South East Asian Nations and at the UN (15 September 2005). Also, "Chinese President Calls for Building Harmonious World," Embassy of the People's Republic of China in the United States of America (24 September 2009) at <http://www.china-embassy.org/eng/zt/t6o7038.htm> (searched date: 24 June 2019).

9 Zheng Bijian, “China's 'Peaceful Rise' to Grate Power Status", Foreign Affairs, no. 5 (September/ October 2005): 18-24 (searched 15 June 2019). Zheng Bijian was Chair of the China Reform Forum, a nongovernmental and non-profit academic organization. He has drafted key reports for five Chinese national party congresses and held senior posts in academic and party organizations in China. 
strategy and influence actions outside the domestic sphere for the long-term benefit of the country. This objective pursued through economic and political means is, indeed, another source of apprehension of the Western liberal society. Recently, all these aspects, only theoretically anticipated under the $\mathrm{Hu}$ Jintao leadership, have been more practically put into action by the current president Xi Jinping through several international initiatives, for example, actively encouraging the organisation of summits with leaders of the world and proposing China as a capable international mediator but more in practice with economic events (i.e. World Expo) and projects, such as the One Belt, One Road initiative.

\section{The One Belt, One Road Initiative}

The One Belt, One Road initiative of economic cooperation is an ongoing complex infrastructural project that presents China as an aggregating international force in achieving global economic development. ${ }^{10}$ At the same time, it contributes to enhancing the Chinese influence around the world in accordance with the goal of improving the Chinese international reputation as an effective contributor to the world. As underlined with evidence by many scholars, politicians and journalists, the entire project is not immune from critics, and the criticisms mainly concern the political influence exercised by China over the participating countries and the advantages acquired by Chinese enterprises. The initiative is considered a political tool and, more commonly mentioned, as a 'debt trap' or a strategic expedient used by the Chinese 'debt diplomacy' to gain economic benefits for its own industries and political influence on Asia and the globalised world. ${ }^{11}$ Some scholars have also compared the initiative with a 'Marshall plan'12 for Asian countries under the leadership of China and therefore is viewed as an economic project implemented to gain military supremacy in the region. From a military point of view, it can be seen

10 Tekdal, V. (2018) China's Belt and Road Initiative: at the crossroads of challenges and ambitions, The Pacific Review, 31:3, 373-390, DOI: 10.108o/o9512748.2017.1391864; Leverett, F. and Wu, B. (2016). The New Silk Road and China's Evolving Grand Strategy, The China Journal, no. 77. 1324-9347/2017/7701-00o6; Ploberger, C. (2017) One Belt, One Road-China's new grand strategy, Journal of Chinese Economic and Business Studies, 15:3, 289-305, DOI:10.1080/14765284.2017.1346922.

11 Taplin, N. (2019). "One Belt, One Road, and a Lot of Debt; Is Beijing strong-arming borrowers with 'debt-trap diplomacy'?” Wall Street Journal (Online); New York, N.Y. 02 May 2019 (searched 6 June 2019).

12 Shen, S. and Chan, W. (2018). A comparative study of the Belt and Road Initiative and the Marshall plan Palgrave Communications, Dec. 2018, Vol. 4(1). 
as an alternative source of supply (by land) to circumvent the possibility of losing control of sea navigation (i.e. naval blockade from the US navy), which is considered the main weakness of the current defensive military system of China and the field in which the United States still maintains a considerable advantage in terms of capability and resources.

To reject these 'defensive' assumptions, Chinese scholars ${ }^{13}$ represent the project as a paramount contribution of China to the world, one that is rooted in traditional Chinese peaceful philosophy. They argue that in the course of its long history, China has always developed a kind of harmonic and peaceful policy of solidarity in appreciation of cultural diversity and that in planning the Belt and Road project, China has revealed its outstanding contribution to global society. Despite this inclusive perspective, the project foundation and philosophy still raise confusion and doubts among Western observers. As some Chinese scholars argue, these suspicions are rooted in the fact that the main basic principles of Chinese culture are unknown to Westerners simply because they have never been at the foundation of their civil societies. For example, these scholars remind the constant idea of 'yin' and 'yang' in Chinese society, that is, the need for balancing opposing forces that disrupt each other to maintain stability and harmony. This key concept of interpretation behind the Chinese vision of a connected and inclusive global society escapes foreign minds. ${ }^{14}$ These ideas have penetrated social customs, and any scholar or individual with knowledge of Chinese philosophy is aware of the significance of this cultural principle.

However, reality shows some contradictions with this Chinese philosophy. The reaction to some evident economic advantages acquired by Chinese enterprises and financial institutions, particularly in Asia, has not generated enthusiastic support for the Chinese vision of cooperation and solidarity. The Belt and Road initiative involves an expensive and complex integration of infrastructural works to be functional and operative. Whereas some of China's neighbouring governments are still at the initial stage of the status of being developing countries, China maintains the role of undisputed leader in handling technology and financial resources. Asian governments participating in the initiative usually have no ability and capability to pursue their own resources for the project and therefore rely on the initiator, China, to provide both financial resources and technical know-how. Chinese multinationals are always in the frontline to get projects' leadership, and for the same reason, the

13 Zhang, W. (2019). The "Belt \& Road" Initiative and Its Chinese Traditional Philosophical Root, International Relations and Diplomacy, March 2019, Vol. 7, No. 03, 110-121. 
outcome is not a balanced win-win solution with the joint partners. The high cost of indebtedness and the need to import technology and skilled human resources can make the 'opportunity' unbearably expensive for the hosting countries.

In the process of leading the initiative, China insists on taking the 'moral responsibility' of the project completion and has implemented a complex organisation aiming to support the countries joining it. On 25-27 April 2019, Chinese President Xi Jinping hosted the second Belt and Road forum in Beijing and invited the high-profile ministries and delegates of the countries supporting the project. During the event, President Xi addressed the main criticisms about the initiative, toning down the rhetoric built in recent months about the 'debt trap' and instead reassuring the partners about the sincere Chinese commitment. Xi also vowed 'zero tolerance' on corruption as a matter concerning not only the project but also the Chinese national policy, while People's Bank of China Governor Yi Gang addressed the financing and investment issues in a common framework of 'debt sustainability'.

However, words of reassurance are not enough for the world. These ongoing contradicting situations have built a sceptical interpretation of the peaceful and harmonic intentions of China. The immediate practical consequences are visible in the complex negotiation on implementing the initiative in the borders of the European Union, the Western destination of the Belt and Road initiative, which inevitably will be longer and more articulated than probably expected by the Chinese government. ${ }^{15}$

The initiative has just preliminarily touched the borders of Europe, and the list of infrastructural works to enhance the project in the European territory includes complex intermodal terminals (ports, railways, logistic facilities, industrial zones, etc.) facing the Atlantic Ocean and the Mediterranean Sea. These intermodal terminals are all strategic solutions for the project realisation as a point of intersection between the demand and supply of goods and services among the regional markets of three continents (Asia, Africa and Europe) with a great impact on global trade. So far, Chinese enterprises have acquired important logistic facilities, such as the Piraeus Port in Greece (by the cosco Group), which, together with the participation of the Rotterdam port logistic handling facilities and the recently announced negotiations in Italy (Trieste

15 Casarini, N. (2016) When All Roads Lead to Beijing. Assessing China's New Silk Road and its Implications for Europe, The International Spectator, 51:4, 95-108, DOI: 10.1080/03932729.2016.1224491; Pepermans, A. (2018). China's 16+1 and Belt and Road Initiative in Central and Eastern Europe: economic and political influence at a cheap price, Journal of Contemporary Central and Eastern Europe, 26:2-3, 181-203, DoI: 10.1080/25739638.2018.1515862. 
Port), will complete a comprehensive network of sea transportation facilities able to handle the expected flow of trade between Europe and Asia.

The reaction of European governments to Chinese investments reveals not only an understanding of the opportunity derived from an inclusive participation in the project but also the need for a collective strategy to enhance negotiation power and redistribute benefits. The most likely outcome is that China and its own enterprises will share the leadership of strategic projects with European Union enterprises. Chinese institutions will remain important stakeholders of the project, but they will not handle the governance of infrastructural projects in the European territory. This solution will avoid the involvement of Chinese entities in disputes with the European Union authorities and the feared effects of 'debt diplomacy' on the European side.

The future development of the initiative in the European Union has important consequences for the future relations between China and the Western world. ${ }^{16}$ The project will represent the inevitable close encounter between two very different models of making political and economic decisions as well as a 'test of truth' for China to overcome the preconceptions and misunderstandings in the Western society. In this context, China can finally show its sincere intention of cooperating with the Western world, providing full support to the project and surrendering its leadership to the European Union territory to accomplish the final goal of international progress and integration that it always proclaims. Needless to say, it will be a long path leading to the conclusion of the project.

Another challenge for China in achieving a 'peaceful ascent' in the global order is described by scholars in power transition theory. This theory, which is generally accepted as an explanation to the inevitability of the historic decline of hegemonic powers, assumes that in the global order, a rising power will inevitably challenge the existing leading power by initiating a war to overturn the dominant position in the world order. Powers have risen and fallen since the beginning of the history of humanity, with some assuming a hegemonic position and others disappearing from the global hierarchy. History has many examples from Spain and England in the 16th century or Germany and Great Britain during the First World War, but also notable cases, in which the

16 Zhao, M. (2016) The Belt and Road Initiative and its Implications for China-Europe Relations, The International Spectator, 51:4, 109-118, DOI: 10.1080/03932729.2016.1235819. 
transition happened without the occurrence of a military conflict. The passage from the so-called Pax Britannica to Pax Americana ${ }^{17}$ took place without the necessity of a war conflict. It was an inevitable voluntary and almost natural transition from the age of a declining (British) empire to that of a strong (American) economic and political mighty hegemon.

The reasons that can escalate the situation to a status of war are discussed by scholars, and Allison's Thucydides trap, ${ }^{18}$ as earlier mentioned, is currently one of the most recurrent cited examples of power transition. In the development of the challenge between super powers, one should not underestimate the fact that not only can the existing leading power feel the pressure of the challenge (as in Allison's arguments) but also the rising power can likely perceive and react to the constraints imposed by the current leadership. Political self-victimisation can lead to extreme consequences that call for the action of a patriotic spirit to defend the national interests, for example.

Although several politicians and scholars have argued that power transition theory is only political speculation, that the assumptions are flawed and, more importantly, that it cannot be related to China because never has an Asian power challenged the hegemony of the Western World in the past, other analysts and observers support such a view and have sent alarm signals to the international society. For example, Chinese 'orthodox' political theorists ${ }^{19}$ emphasise the fundamental standing point that China is not committed to the process of democratisation. The liberal society assumes that democracies do not pursue war in disputes and challenges but that different political regimes, particularly authoritarian ones, do not follow this peaceful pattern of conduct.

Whatever the next Chinese move is, what makes the Western world suspicious is the sense of detachment and often the uncommunicative attitude of Chinese leadership perceived by Western analysts as warning signals of unexpected decisions. Among the sceptical authors explaining the Chinese political behaviour, Edward Friedman describes the Chinese strategy ${ }^{20}$ as constantly making use of international organisations to become a disruptive member of the international society, for example, by becoming a wTо member but not entirely fulfilling the requirements, accepting World Bank loans and entertaining an apparent collaborative relation with the International Monetary

17 Breslin, S. (2013). China and the global order: signaling threat or friendship? International Affairs (Royal Institute of International Affairs 1944-), Vol. 89, No. 3, Negotiating the rise of new powers (May 2013), pp. 615-634.

18 Graham, A. (2017). Destined for war. Houghton Mifflin Harcourt.

19 Deng, Y. (2008). China's Struggle for Status, New York: Cambridge University Press.

20 Friedman, E. (2010). A Challenge to the Peaceful Rise of World Power in China in Yee, H.S. (Ed.). (2010). China's rise - threat or opportunity? Routledge Security in Asia Series. 
Fund but at the same time ignoring the norms of missile non-proliferation, building its own supply network in the oil market with African countries and organising its sovereign investment fund to circumvent the international rules of transparency. In playing this deceiving role, China sometimes appears conveniently as a revisionist (anti-status quo) or an integrationist country but constantly acts in the own interest. The policy of internationalisation of the Chinese currency, $\mathrm{RMB}$, can also be interpreted as a message of independence from the American leadership to become an equal competitor in the current geopolitical system. A strong leading nation has always exercised its own economic power through a strong currency since the beginning of modern civilisation, and China will not make an exception to it.

In matters of international cooperation, China prefers debating on international issues in the ASEAN or BRICS organisation rather than participating in organisations led by and extended to liberal democracies, such as the United States. In terms of the peace process, China has become part of the United Nations Peace Keeping Organization as a main contributor to military personnel. This effort is also seen with suspicion as a means to ensure that the European Union and the United States cannot use the institution to promote democracy around the world.

In its own way, China rejects the values of a Western-dominated society and builds a network of allies and partners to balance the Western supremacy by opening suspicious dialogues with the most (politically) isolated countries, for example, North Korea and Iran. According to Friedman, these facts are supporting elements that lead to the conclusion that the clash is inevitable, as proposed by power transition theory. ${ }^{21}$

To be consistent in evaluating both antithetic positions, we should consider how to interpret the current complex reality by pondering on the contradictions involving the conflictual theoretical approach of power transition with the openly proclaimed Chinese peaceful rise intentions. In examining all the elements, we should not forget to balance our judgment with contradicting evidence. Scholars such as Steve Chan ${ }^{22}$ argue that we should consider the possibility that China does not intend to have a direct conflict with the United States or other members of the Western world simply because the consequences are not aligned with China's ambitions of enhancing its economic development and prosperity. China aims to build recognition for its 'well-deserved'

\footnotetext{
21 Friedman, E. (2010). A Challenge to the Peaceful Rise of World Power in China in Yee, H.S. (Ed.). (2010). China's rise - threat or opportunity? Routledge Security in Asia Series. 
role as an international power. The country is evidently not yet ready to be a 'hegemon' because Chinese leadership has a conscious and clear understanding of the fragility of its own system, which currently cannot compete as an equal in matters of economic, military and technological advancement. A premature confrontation will not bring benefits to China, as it could cause disastrous consequences in the entire idea of a 'Great China' as a member of the global society. ${ }^{23}$ Examining the current relations between China and the United States, Chan observes a deep economic interdependency as an element of reciprocal vulnerability. The dramatic evidence of the ongoing trade war shows certain undeniable endogenous weaknesses, particularly for China. Therefore, China's strategy should opt for deflecting direct pressure, avoiding direct confrontations and rejecting situations in which both powers can be inescapably entangled in a conflict rather than engaging in direct confrontations. Chan asserts that China wanting to take the world leadership should be the opposite behaviour expected by scholars supporting power transition theory. If the final goal is indeed to seize the role of global leadership, then China will not use military force but instead encourage the dominant power to overstretch its hegemonic ambitions, build over-confidence and encourage entanglements in many fronts to gradually weaken the dominant power. ${ }^{24}$ These are the political and strategic behaviours that the current American administration is actually and wisely managing in an opposite manner.

What can truly lead to a conflict between superpowers is related to China's sensitive 'domestic' affairs, in which China is unwillingly called to debate its own One-China policy with the Western world. These aspects can be a cause for more extreme reactive measures because of certain standing points considered by the Chinese leadership as inviolable in protecting its sovereignty from foreign interferences. I refer to the political and social situations in Tibet, Xinjian and Taiwan (and, more recently, Hong Kong), which can explain the Chinese attitude and position in international governance. These are non-negotiable matters for the Chinese government because they touch the aspects of national stability and integrity. The questions raised through political pressure in debates or media by the international community regarding, for example, the freedom of expression in Tibet, Xinjian and the independence of Taiwan are unequivocally considered interferences in domestic matters and are non-negotiable.

\footnotetext{
23 Chan, S. (2013) Geography and international relations theorizing: their implications for China, Eurasian Geography and Economics, 54:4, 363-385.

24 Chan, S. (2007). China, the US and the power-transition theory: A critique. Routledge, p. 95.
} 
Among these questions, the issue of Taiwan is the most relevant and potentially devastating in maintaining peace and stability in the current international order. For China, this issue is an unsolved priority in terms of sovereignty and territorial integrity and the last obstacle to achieving national reunification. Taiwan or Chinese Taipei, as more commonly used in Chinese state official documents, is the possible borderline where dominant and rising superpowers confront each other to attain either a peaceful coexistence or a permanent status of tension.

Nowadays, Taiwan does not have the strategic value of being a bastion of anti-communism anymore, as interpreted by Gen. MacArthur in the 1950s. This image disappeared with Washington's recognition of the People's Republic of China in 1979. Instead, Taiwan has a geographical strategic position in the South China Sea between Japan and the Philippines on a sea route through which trade and oil transit frequently. Today, Taiwan is becoming increasingly important more for its economic and military position but less as a political and ideological symbol of resistance. ${ }^{25}$

The question is whether China would risk losing its achievements and recognition of being part of the international leadership for a relevant 'domestic' matter of geographical territory. The answer can be found in history. Waging war does not bring popularity or more power. Conflicts do not bring progress and prosperity and certainly not a leadership role for the countries leading their nations to destruction and human losses. Europe has inexorably withdrawn from being an important geopolitical and military global leader after initiating and staging two World Wars. History has also taught us that the moral quality of leadership is the most qualified reassurance that discourages wars. In the age of nuclear powers such as China and the United States, the consequences of a conflict will be devastating for humanity, and they will be worse for the ideal process of progress and advancement of the involved nations. As far as China is concerned, as Chan argues, all the previously mentioned risks and weaknesses suggest that the current Chinese strategy does not seem to be one of a rising world hegemon but that of a strong country searching for a regional (Asian) leadership role rather than being an impatient newcomer determined to challenge or change the existing international order. ${ }^{26}$

25 Chow, C.Y. Peter (edited by). (2014). The US strategic pivot to Asia and cross-strait relations: economic and security dynamics. New York, Palgrave Macmillan, p. 179.

26 Chan, S. (2013) Geography and international relations theorizing: their implications for China, Eurasian Geography and Economics, 54:4, 363-385. 


\section{$5 \quad$ More Considerations about the Harmonious International (Socialist) Order}

As so far argued, China's political role and economic relevance are strongly linked to the achievement of the 'harmonious' and peaceful global order. The fact that the entire idea of a 'Great China' is built on the fundamental assumption that only a world at peace can bring prosperity for the Chinese nation and give recognition to China as an important power in international society should not be underestimated.

The emergence in the world of any kind of conflict that affects international political instability and economic volatility in the international markets does not support the long-term consolidation of the socio-economic results achieved by China in recent years. This awareness of the need for peace and harmony guides Chinese leadership in pursuing consistent policies in domestic and international affairs. Achieving this goal requires 'orderliness', that is, national and international order must be maintained and protected.

National society should be in harmony and unified. Different interests should be reconciled in a balanced environment of 'equity and justice'. Stability encourages social vitality and supports innovative and creative ideas. ${ }^{27}$ The domestic vision of society reflects the Chinese vision of international order, in which China's role could be that of a constituent guarantor and leader, promoting peaceful prosperity and cultural coexistence.

The entire accomplishment of the Chinese 'order' requires a high degree of international reciprocity and cooperation. It is based on multilateralism in international relations, on an unshakable faith in the principle of sovereignty and on the ability to negotiate any important issue concerning the globalised world. ${ }^{28}$ Today, the Chinese international policy is built on the 'Five Principle of Peaceful Coexistence': respect for sovereignty and territorial integrity, non-aggression, non-interference, equality and mutual benefit and peaceful coexistence. In the Chinese political ideology, expressions of hegemonism and imperialism remain the prevailing political adversaries. For this reason, China considers the role of the United Nations paramount to the project not only because China is a permanent member of the

\footnotetext{
27 Yu Keping (2009). Democracy Is a Good Thing: Essays on Politics, Society, and Culture in Contemporary China, Brookings Institution Press pp. 168-180.

28 Wu, X. (2018). The "Chinese Approach" Ushers in a New Model of Global Governance Civilization, Social Sciences in China, 39:4, 139-153, DOI: 10.1080/02529203.2018.1519229.
} 
Security Council and can exercise its role of 'balancing power' but also because the United Nations represents the only institution in the current international order in which the world can handle threats and challenges to humanity. Therefore, China greatly supports the role and authority of the United Nations.

The United Nations represents the organisation in which multilateralism in international relations has been used through diplomacy since the end of the First World War as a means of cooperation and communication among the nations of the world. The principle of sovereignty has been statutorily (United Nations Charter) affirmed and accepted as the foundation of the current international order. The United Nations was created as an intergovernmental decision-making model, in which the instruments of negotiation essentially rely on the willingness of countries to freely cooperate and achieve an international compromise in important international affairs. However, has this organisational model so far achieved the goals of harmony and peaceful coexistence in global society?

Despite all the efforts and attention given by the global community mainly through the United Nations organisations, the current order witnesses an incongruent trend of protectionism in economic policies: the constant peril of an imminent war in some areas of long-lasting instability largely remains unsolved (i.e. Middle East); terrorism is periodically a threat to the sociopolitical stability of nations (i.e. ISIs); and other more complex forms of conflicts are affecting the global order, such as the war on illegal drugs and international cartels and the new developments in advanced technology, including the threat of a global cyberwar, which can suddenly destabilise the entire global society.

If we look at the undeniable evidence, the current international order appears ineffective and, in some cases, probably obsolete for a global society willing to solve such important and complex issues. Multilateralism, the international law principles of sovereignty and non-interference in states' domestic affairs, and the entire structure of the intergovernmental model of the current international order, unfortunately, have failed to achieve peace and harmony for the world. The global community, including China, should reconsider the strategy of achieving the dream of a cosmopolitan, peaceful society, even considering a supra-national socio-political model built on surrendering rather than asserting sovereign powers and in which country borders are less relevant than human rights and international law principles. This vision of a global society, as undeniable evidence shows, is still too far to be reasonably achieved, and it seems that it is not the one supported by the Chinese vision of a 'harmonious order'. 
All nations today have acknowledged the impressive and unprecedented social and economic transformation achieved in a few decades by China. This achievement was completely unexpected by the West because it was accomplished by an Asian country, specifically by China, a nation ruled by the communist ideology and too often tempted to live in a historical and selfimposed isolationism. Now, China can finally claim an influential political role in international affairs.

China's 'socialist' proposal of a harmonious world order aims to confront the major issues of human society with the intention of overcoming global obstacles and conflicts using a binding and egalitarian force so strong that it can maintain the unity of intentions among nations. This vision, which is based on a political constructive cooperation, seems to strongly contradict the realist political vision of unilateralism and hegemonism, which has shaped the international order and the system of international relations for centuries. The Chinese proposal opposes the current reality of 'Pax Americana' (or the eventual 'Pax Sinica') and rejects the idea of recurring changes in world governance and leadership. The strong contrast between the peaceful and constructive vision of a harmonious society and the historical inevitability of a hegemonic presence makes the Chinese proposal and the understanding of China's intentions almost impossible to be trusted.

The end of the Cold War unexpectedly gave China the opportunity to integrate itself into the international system. In this context, China reviewed its foreign policy and proposed itself as a global partner, accepting the rules of the current world organisation. However, it is exactly because China has become part of this international order that it is now subject to scrutiny by the same system and in accordance with the existing principles governing it. China's actions are considered in the framework of the traditional political model, in which a leader (hegemon) inevitably periodically rises, and realism (as the prevailing political belief) rules politics in a perverse trend of ascending and declining powers. Therefore, despite all the good (still to be proved) intentions, China's leadership is destined to find opposition from a still Western-dominant world, which is not ready to believe in a new model of coexistence.

Another important aspect of the friction between China and the West is the contradiction of a 'socialist' nation, such as China, being integrated into a liberal (capitalist) global model of society. With the advent of globalisation, connections and transformations have changed the shape of the world. Capitalism has created the possibility of opening nations to a new perspective of fast and unlimited exchange of ideas, goods and mobility of people. For 
Western scholars who study China from a political perspective, the fact that China now wants to be part of a process (globalisation) funded and supported by the liberal democratic system is a contradiction. ${ }^{29}$ Even if China is ready to accept the model of liberal globalisation, how does its political leadership intend to fit in and on which ideological foundation will it be based?

In principle, China, to be credible, should not adhere to the globalised world as an economic expression of Western capitalism just because it implies accepting Westernisation or specifically the Americanisation of the society, in which the United States has been a symbol of capitalism and imperialism strongly opposed by China. However, several elements of globalisation are interesting and appealing to the Chinese leadership, such as the idea of an international economic interaction of forces in exchanging goods and services (i.e. One Belt, One Road) and the social and cultural interrelations that open the frontiers of solidarity and cooperation (i.e. Confucius Cultural Offices). Through these ideas and projects, China can reach and acquire the resources it needs to pursue its own development goals and promote its own cultural image. Evidently, China has emerged a winner in globalisation, and its government has mastered the key strategies and measures to maximise the results of participating in the global system without losing control of its domestic governance. Controlling domestic policies and society is important for China. The political leadership has perceived and learned the negative effects of being part of an open, accessible world. Foreign corporate control in Chinese strategic industries and the possibility of participating in important domestic infrastructural works have been limited so far. Capital inflow is welcomed but strictly regulated, whereas outflow is monitored and preliminary authorised.

Overall, these actions reveal an attitude of China that is similar to that of other protectionist countries in the world and not consistent with the open context of globalisation. China has entered into a wide range of international agreements and arrangements but developed a protective strategy at the same time to draw maximum advantage from the open trade and capital flow, trying its best not to sacrifice its ideological values, resources and own political agenda.

On one hand, the Chinese proposal provides an idea of a post-hegemonic system based on multilateralism, common prosperity and a global risk

29 Friedman, E. (2010). A Challenge to the PeacefulRise of World Power in China in Yee, H.S.(Ed.). (2010). China's rise - threat or opportunity? Routledge Security in Asia Series; Breslin, S. (2013). China and the global order: signaling threat or friendship? International Affairs (Royal Institute of International Affairs 1944-), Vol. 89, No. 3, Negotiating the rise of new powers (May 2013), pp. 615-634. 
management task force to overcome the weaknesses of the system, international crime, terrorism and sources of financial crises and to promote tolerance in a world of diversities. On the other hand, for sceptical (Western) scholars, politicians or journalists, such an empathetic vision hides the shadows of a non-Western (and therefore suspicious), state-centric idea proposed by an authoritarian regime in search of international consensus. Will China's harmonious coexistence and governance finally be achieved? Efforts to convince the world of China's genuine intentions require more convincing facts and time. For now, that path seems full of hurdles, and the goal is still too far to be accomplished. 